\title{
IMPROVING ETHICAL AND AESTHETIC EDUCATION OF PERSONAL CREATIVITY IN FUTURE TEACHERS
}

\section{Khol Jumaevich Khudoykulov}

Professor, Department of "Pedagogy And General Psychology", National University Of Uzbekistan Named By Mirzo Ulugbek, Doctor Of Pedagogical Sciences, Uzbekistan

Farida Abdukhalilovna Toshboeva

Independent Researcher, Department Of Preschool And Primary Education, Denau Institute Of Entrepreneurship And Pedagogy, Uzbekistan

\section{ABSTRACT}

Today in almost all spheres of social life there is a significant increase in the importance and status of individual creativity, the rapid creation and implementation of innovative technologies and new creative ideas by people with mature, creative, highly intellectual and artistic-aesthetic qualities. can be increased. The issue of moral and aesthetic education, which plays a key role in the formation of a creative personality, plays an important role in the structure of the educational process. This article substantiates the need for the formation of moral and aesthetic consciousness in future professionals, taking into account the principles of high universal and national ideas.

KEYWORDS:- Personality creativity, moral and aesthetic consciousness, education, intellectual development, independent thinking, loyalty to the Fatherland, upbringing of youth, system of moral and aesthetic education.

\section{INTRODUCTION}

At the current stage of development of the world community there is a significant increase in the importance and status of individual creativity in almost all spheres of social life, as the rapid creation and implementation of innovative technologies and new creative ideas have a mature, creative, highly intellectual and artisticaesthetic features. can be done by humans. The process of creative formation of each individual plays a very important role in solving these global tasks. On the basis of the humanistic concept of education, special emphasis is placed on the high value of the individual, the priority of the ideas of cultural and ethnic diversity in social development ${ }^{1}$.

The essence of pedagogical processes is also changing as a result of unprecedented changes in cultural, historical and social conditions around the world. This requires relying on existing experiences and innovations, innovative

\footnotetext{
${ }^{1}$ Inncheon declaration/Education 2030: Towards inclusive and equitable quality education and lifelong learning for all (Word Education Forum, 19-22 may 2015, Incheon, Republic of Korea).
} 
CURRENT RESEARCH JOURNAL OF PEDAGOGICS 2(10): 125-132,

October 2021 DOI: https://doi.org/10.37547/pedagogics-crjp-02-10-24

ISSN 2767-3278

(C)2021 Master Journals

\section{Crossref doi) google}

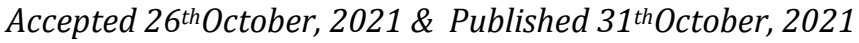

approaches. This idea is the main principle of the education system, which is the main link of sociocultural heritage, and reflects the purpose of the educational process, its content, form and methods, the interaction of teachers and students, their impact on their activities. The issue of moral and aesthetic education, which plays a key role in the formation of a creative personality, plays an important role in the structure of the educational process.

In the introductory part of the topic, based on the relevance of the research topic, the level of study of the problem is described

In the process of continuing education in Uzbekistan, one of the main forms is the formation of the personality of young people and their upbringing as harmoniously developed people. The state education policy pays special attention to the need to educate students based on national and universal values. The Action Strategy for the Further Development of the Republic of Uzbekistan states that "training of highly qualified personnel in accordance with the modern needs of the labor market, increasing access to quality educational services, improving the quality and efficiency of higher education institutions, further improvement of the system of comprehensive intellectual, moral and aesthetic education" 2 .

This, in turn, requires that science programs focus on the further improvement of educational technologies, the search for effective means of education and the process of personal development of the future specialist.

PF-4947 of the President of the Republic of Uzbekistan dated February 7, 2017 "On the

\footnotetext{
${ }^{2}$ Decree of the President of the Republic of Uzbekistan dated February 7, 2017 No PF-4947 "On the Action Strategy for further development of the Republic of Uzbekistan." Collection of Legislation of the Republic of Uzbekistan, 2017, No. 6, Article 70.
}

Action Strategy for further development of the Republic of Uzbekistan", PF-5106 of July 5, 2017 "On increasing the effectiveness of state youth policy and support the activities of the Youth Union of Uzbekistan" Decrees No. PP-2909 of April 20, 2017 "On measures to further develop the system of higher education" This dissertation research to some extent serves to implement the tasks set out in the Resolution No. 3151 of July 28, 2017 "On increasing the effectiveness of spiritual and educational work and raising the development of the industry to a new level" PQ3160 and other regulations related to this activity.

To study the problems of improving the process of moral and aesthetic education of youth in our country have done research works by U.Aleuov, E.Bobomurodov, M.Inomova, Sh.Kurbanov, Sh.Mardonov, U.Makhamov, O.Musurmonova, A.Muminov, A.Sulaymonov, F.Khalilov, X.J.Khudoykulov, A.Erkaev, K.Yuldashev, and others. At the same time, various aspects of this problem were discussed by CIS scientists AIBurov, M.A.Verba, EVKvyatkovsky, BTLikhachev, G.Bolkhovsky, N.A.Vetlugina, OSBogdanova, KV Gavrilovets is also reflected in the research of OS Ivashchenko. The problems of moral and aesthetic education can also be seen in the scientific research of foreign scientists $E$. Eisner, R. Smith, R. Schusterman, P. Parrish, H. Fairbank, M. Holzer, A. Gulla and others.

Thus, the problems of moral and aesthetic education of mainly secondary school students are being studied intensively and extensively today. However, to date, no special research has been conducted to improve the process of moral and aesthetic education of students in the higher education system, including future teachers, on the basis of a person-centered approach, and this issue needs to be addressed.

The main purpose of the analysis of this topic is to improve the process of moral and aesthetic 
CURRENT RESEARCH JOURNAL OF PEDAGOGICS 2(10): 125-132,

October 2021 DOI: https://doi.org/10.37547/pedagogics-crjp-02-10-24

ISSN 2767-3278

(C)2021 Master Journals

Crossref doi) $\mathrm{g}^{\prime}$ Google

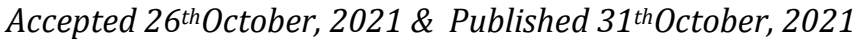

education of future teachers on the basis of a person-centered approach.

\section{We consider its functions as follows:}

- to determine the possibility of implementing an approach aimed at the formation of the future teacher on the basis of an analytical study of the state of moral and aesthetic education of students in higher education institutions;

- development of a pedagogical model that combines the theoretical and practical aspects of moral and aesthetic education of future teachers on the basis of a personcentered approach;

- to reveal the didactic possibilities of improving the content of pedagogical disciplines taught in the bachelor's degree programs in the field of education "Pedagogy" in order to increase the effectiveness of moral and aesthetic education of students;

- to determine the criteria of moral and aesthetic education in the process of forming the personality of the future teacher and to develop practical recommendations for improving pedagogical forms and tools;

- the process of moral and aesthetic education of students studying in pedagogical directions of higher education institutions was chosen as the object of the topic, the process of teaching pedagogical disciplines in UrSU, Bukhara State University and Navoi State Pedagogical Institute (Pedagogy and Psychology, Primary Education and Sports, Preschool Education) A total of 450 respondents were involved in the testing.

- The subject of the chosen subject is the content, forms, methods and means of moral and aesthetic education of students studying in pedagogical directions of higher education institutions on the basis of a person-centered approach. Research methods of observation, interview, questionnaire, comparative analysis, pedagogical experiment, mathematical statistics were used during the research.

- The scientific novelty of the topic is:

- the process of moral and aesthetic education of students in higher education institutions on the basis of a person-centered approach has improved the content of the disciplines "Theory and History of Pedagogy", "Pedagogical Skills", "Pedagogical Technologies";

- a set of theoretical aspects, principles, factors, effective methods, forms and tools of a perfect pedagogical model of moral and aesthetic education of the future teacher, oriented to the person;

- criteria for moral and aesthetic education of future teachers are developed on the basis of technologicalized theoretical and practical training on ethical and aesthetic topics in the educational process of higher education institutions and a person-centered approach;

- scientific-theoretical and methodological recommendations for improving the process of moral and aesthetic education of undergraduate students in the field of education "Pedagogy" of higher education institutions on the basis of a person-centered approach.

\section{Its practical results are as follows:}

- a pedagogical model has been developed that includes effective methods and tools of moral and aesthetic education of the future teacher;

- developed proposals for improving the curriculum in the disciplines "Theory and History of Pedagogy", "Pedagogical Skills", "Pedagogical Technologies" taught in the 
CURRENT RESEARCH JOURNAL OF PEDAGOGICS 2(10): 125-132,

October 2021 DOI: https://doi.org/10.37547/pedagogics-crjp-02-10-24

ISSN 2767-3278

(C)2021 Master Journals

\section{Crossref doi) gr Google}

Accepted $26^{\text {th }}$ October, 2021 \& Published $31^{\text {th }}$ October, 2021

bachelor's degree programs in the field of "Pedagogy";

- practical recommendations for improving the system of moral and aesthetic education of students, including effective organizational and pedagogical methods, techniques and tools.

Reliability of the results is based on modern methodological principles, reliable theoretical and pedagogical and practical foundations, the gradual dynamics of quantitative and qualitative results in control and experimental groups in the process of real practice and the accuracy of their comparison, mathematical statistical methods of experimental results. This is explained by the fact that the results of the study were put into practice and approved by the competent authorities in the prescribed manner.

\section{Theoretical and practical significance of the topic.}

The study identifies a conceptual-methodological approach to solving the problem of moral and aesthetic education of the future teacher on the basis of a person-centered approach, the basic theoretical and pedagogical rules, theoretical and fundamental concepts of moral and aesthetic education. In order to improve the personality of pedagogical staff in the study of general pedagogical disciplines developed criteria for moral and aesthetic education of future teachers. The pedagogical system developed on the studied subject, the content of which is based on the modification of curricula in general pedagogical disciplines, developed a pedagogical model aimed at the moral and aesthetic education of the future teacher. The principles, factors and psychological and pedagogical conditions that serve to find a solution to the problem under study are identified. To professors and students of higher education institutions; the educational process; Theoretical and practical requirements for the content of the tasks and educational and creative work assigned to students, the activities of students (requiring moral and aesthetic knowledge, understanding, imagination, feelings, qualities and abilities) are developed.

The practical significance of the research lies in the fact that the theoretical and pedagogical rules, theoretical and practical results, recommendations developed in it, the staff of the Ministry of Higher and Secondary Special Education in their activities related to the production of instructions and recommendations; use by pedagogical scientists in their methodical and scientific work; In improving the curricula of general pedagogical disciplines taught in the areas of education in the field of education "Pedagogy"; in the development of textbooks and methodological recommendations for the moral and aesthetic education of future teachers; can be used in the educational work of academic group leaders.

Introduction of topic results. Scientific results of improving the moral and aesthetic education of students studying in pedagogical areas of higher education on the basis of a person-centered approach:

A1-KX-1-60888 - "Strategy for the formation of self-awareness and self-expression in the form of basic personality traits in secondary school students" (2014) was implemented in the implementation of the practical research project;

Implemented by the methodical recommendation "Ethical and aesthetic education of students in the teaching of pedagogical disciplines (Methodical recommendations)" recommended for publication by the decision of the Educational and Methodological Council of Urgench State University No. 21.02.2017;

Experimental work carried out at Bukhara State University, Navoi State Institute, Urgench State 
CURRENT RESEARCH JOURNAL OF PEDAGOGICS 2(10): 125-132,

October 2021 DOI: https://doi.org/10.37547/pedagogics-crjp-02-10-24

ISSN 2767-3278

(C)2021 Master Journals

\section{Crossref doi) google}

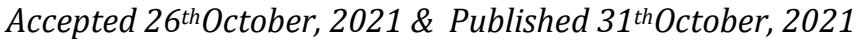

University was put into practice on the basis of the reference of the Ministry of Higher and Secondary Special Education of the Republic of Uzbekistan dated 08.06.2018 No 89-03 2245. While studying the moral and aesthetic education of future teachers as an urgent sociopedagogical problem, it reveals the methodological bases of moral and aesthetic education of young people, the theoretical and pedagogical bases of personal development in the process of moral and aesthetic education, the experience of foreign countries in developing modern systems of this type of education. Constructive and positive change and improvement of the education system in line with modern requirements, strengthening the focus on practical education in higher education institutions training new specialists, education of certain personality traits, including moral and aesthetic qualities, based on the tasks set in the Action Strategy for further development of Uzbekistan based on methodological-theoretical and practice-oriented principles ${ }^{3}$.

Actively using pedagogical-technological and methodological innovations, focusing on the formation of students' personality, harmonious personality, emphasizing the spiritual-moral and spiritual-aesthetic education of students based on folk art, historical-cultural, nationaltraditional, national-artistic heritage based on universal values is given.

The ideas of great Eastern thinkers, including alBukhari, al-Farobi and, in particular, Alisher Navoi, on moral and aesthetic education are widely covered in future specialists, based on the need to form a moral and aesthetic consciousness, taking into account the principles

\footnotetext{
${ }^{3}$ Decree of the President of the Republic of Uzbekistan dated February 7, 2017 No PF-4947 "On the Action Strategy for further development of the Republic of Uzbekistan." Collection of Legislation of the Republic of Uzbekistan, 2017, No. 6, Article 70.
}

of high universal and national ideas. In particular, the ideas of Alisher Navoi on moral and aesthetic education, the essence of their content are widely covered. In particular, the moral and aesthetic views of Alisher Navoi, the main moral and aesthetic qualities, attributes and characteristics of man, a symbol of goodness, evil, nobility and beauty, ways of their creation and development in the personality are analyzed and methodologically important cases for research are formed.

Moral and aesthetic education is considered not only as relevant knowledge, qualities and attributes, but also as beautiful, human actions, deeds, deeds, attitudes at the level of ethics and aesthetics. Moral and aesthetic education of future teachers is studied in the sociopedagogical sphere, in the sources of high moral and aesthetic potential derived from the national and cultural heritage, with special emphasis on the formation of moral and aesthetic professional and personal qualities, qualities and abilities. Moral and aesthetic education of future teachers - the development of their moral and aesthetic development, conscious, professional-personal, emotionally-positive attitude, moral-aesthetic knowledge, understanding and imagination; formation of moral and aesthetic qualities, qualities, feelings, attributes and abilities necessary for pedagogical activity; moral and aesthetic education - knowledge of the theoretical and pedagogical and practical foundations, technology, form, methods, tools and techniques of personal development; to bring oneself to personal and professional moral and aesthetic perfection, and at the same time to know and understand the goals of professional and personal development; the use of educational material of high moral and aesthetic importance in the study of general pedagogical disciplines, the raising and socialization of their moral and aesthetic achievements in various activities close to pedagogical activity, objective 
CURRENT RESEARCH JOURNAL OF PEDAGOGICS 2(10): 125-132,

October 2021 DOI: https://doi.org/10.37547/pedagogics-crjp-02-10-24

ISSN 2767-3278

(C)2021 Master Journals

\section{Crossref doi) gr Google}

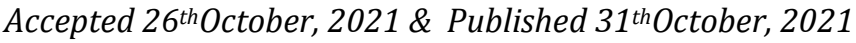

self-assessment. Also, the principles and criteria for the implementation of innovative personcentered approaches in the moral and aesthetic education of future teachers have been developed. The experience of the United States, France, Great Britain, Japan in the field of moral and aesthetic education of young people was studied and analytical conclusions were made on this basis.

Ethical and aesthetic education of future teachers - the principles, factors, system, conditions and content of moral and aesthetic education of students of higher education institutions as an important factor in the development of personality. In particular, the following principles form the system of moral and aesthetic education on the basis of a studentcentered approach: psychological and pedagogical characteristics of students; taking into account the structure, complexity, interdisciplinary connection; integrity and integrity; consistency; adherence to a technological approach, pedagogy; relying on the aspects of positivity and positivity in the selection of educational materials; inculcating humanity and putting the individual in the center of attention; based on national-cultural and universal values.

The main factors of this process are: conceptualmethodological, methodological-theoretical, socio-pedagogical, national-cultural, spiritualmoral and aesthetic, psychological (especially motivational-psychological), interdisciplinary, educational-educational, cognitive-information. systematic, technological, theoreticalpedagogical and practical, intellectual-creative, methodical, and socio-communicative. psychological), interdisciplinary, educationaleducational, cognitive-information systematic, technological, theoretical-pedagogical and practical, intellectual-creative, methodical, and socio-communicative. The structure of the integrated pedagogical model consists of goals, objectives, predicted results, principles and factors, system-pedagogical logic.

The first is the interdependence of pedagogical disciplines. In the Classification of Higher Education Areas and Specialties, the subject "General Pedagogy" is included in the general pedagogical block of the curriculum of almost all undergraduate educational programs, and "Theory and History of Pedagogy" is included in the general pedagogical and specialty subjects, "Pedagogical skills", "Pedagogical technology". Among the requirements for these disciplines in the STS of this field of education are the need to equip future teachers with knowledge of the theoretical and historical foundations of modern pedagogical science and teaching skills, effective use of pedagogical heritage, as well as teaching students spiritual and moral education on the basis of the National Training Program.

Second, the intra-scientific system consists of the following components: motivational-targeted; information-knowledge, education-formative (intellectual-creative, theoretical-practical, independent development of knowledge), socialcommunicative. Particular attention is paid to the motivational and educational-formative stages (essence, content, functionality and effectiveness).

The content of the pedagogical model developed and proposed on the example of the bachelor's degree in "Pedagogy and Psychology" is reflected in the modified programs of general pedagogical disciplines, taking into account the objectives of the study and the established parameters of interdisciplinary communication. Emphasis is placed on the moral and aesthetic effect of the content: the national-cultural and artistic heritage of the Uzbek people, issues of increasing the opportunities of moral and aesthetic education (in the subject "Theory and History of Pedagogy"); technological approach to moral and 
CURRENT RESEARCH JOURNAL OF PEDAGOGICS 2(10): 125-132,

October 2021 DOI: https://doi.org/10.37547/pedagogics-crjp-02-10-24

ISSN 2767-3278

(C)2021 Master Journals

\section{Crossref doi) gil Google}

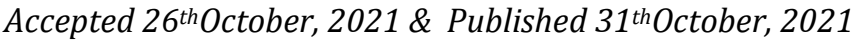

aesthetic education (on the subject "Pedagogical technologies"); creative use of pedagogical bases of moral and aesthetic education (on a subject "Pedagogical skill"). Assignments, general pedagogical disciplines of intellectual-creative and methodical work, moral-aesthetic content

Themes, types, forms of activity of future teachers are developed.

At the same time, the emotional-psychological, psychological-pedagogical, organizationalpedagogical and pedagogical conditions for the successful implementation of this model are identified and studied.

Also, the technology of moral and aesthetic education, the structural and structural components of this education have been developed; thematic cycles of training sessions (lectures, talks, discussions, practical classes, seminars), their structural and semantic bases are technologized; methods, ways and means of moral and aesthetic education of future teachers, including non-traditional and innovative methods are analyzed separately.

Thus, the process of improving the moral and aesthetic education of future teachers on the basis of a person-centered approach has yielded great results. This indicates that the goals and objectives of the study have been achieved and we have come to the following conclusions:

1. The factor of personal development, ie the moral and aesthetic education of future teachers are a topical socio-pedagogical significance and a problem that is not sufficiently studied in practice. To this end, the essence of moral and aesthetic education, the criteria for its formation in future teachers, the experience of moral and aesthetic development of future teachers experimental work has been studied on the basis of the process of studying general pedagogical disciplines.
2. The following factors were the basis for the successful solution of the problem: the improvement and modification of curricula in general pedagogical disciplines serve to effectively solve the problem under study. In the process of modification, the curriculum emphasizes the following interrelated aspects, along with the topics of moral and aesthetic education:

3. Practical solution of the problem to give future teachers a clear moral and aesthetic direction (moral and aesthetic knowledge, the concept of moral and aesthetic education, adequate qualities, qualities, abilities and abilities of the teacher, their role and importance in personal and professional development); related to intellectual and creative work as well as communicative activity (attitude).

4. As a result of practical research on the experimental program in the experimental groups obtained sufficiently high results on all criteria of moral and aesthetic education of future teachers, personal development, which confirmed and justified in a series of step-by-step tables and figures.

5. Recommendations: conceptually important approaches to problem solving; the main theoretical aspects of moral and aesthetic education are shown. The recommendations describe the conditions for successful moral and aesthetic education of future teachers, the development of their personality.

Thus, we hope that the studied topic will be the basis for the moral and aesthetic education of future teachers, its development as a person, and it will bear fruit.

\section{REFERENCES}


CURRENT RESEARCH JOURNAL OF PEDAGOGICS 2(10): 125-132,

October 2021 DOI: https://doi.org/10.37547/pedagogics-crjp-02-10-24

ISSN 2767-3278

(C)2021 Master Journals

Crossref doi) 81 Google

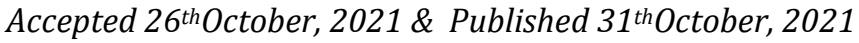

1. Mirziyoev Sh.M. Five priority areas of development of the Republic of Uzbekistan for 2017-2021 "Strategy of action" - T.: "Uzbekistan". 2017.

2. Mirziyoev Sh.M. Republican Department of Spirituality and Enlightenment. Five initiatives-five opportunities. -T .: Politics, 2019.

3. Karimov I. Uzbekistan on the threshold of the XXI century: threats to security, conditions of stability and guarantees of development. -T .: "Uzbekistan", 1997.

4. Karimov I. On the way to security and sustainable development. -T .: "Uzbekistan", 1998.

5. Karimov I. The concept of further deepening democratic reforms and development of civil society in our country. -T .: "Uzbekistan", 2010.

6. Karimov IA High spirituality is an invincible force. -T .: Spirituality, 2008.

7. Sabirova Ch. Moral and aesthetic education of students in the teaching of pedagogical sciences (Methodical recommendations) Tashkent: Sparks of Literature, 2018. - B. 54

8. Sabirova $\mathrm{Ch}$. Theoretical bases of personal development of future teachers in the process of moral and aesthetic education // Teacher and continuous education. - Nukus. 2011. -№6. -B.48 - 51. (13.00.00; - №20).

9. Sabirova Ch. Principles, factors and conditions of moral and aesthetic education of future teachers // Folk education. Tashkent. 2012. - №1. - B. 80-82. (13.00.00; - №17).

10. Sabirova Ch. Technology, forms and methods of moral and aesthetic education of students // Science and society. - Nukus. 2015. №2. - B. 82 - 86. (13.00.00; - №3).
11. Sabirova Ch. On the factors of technological approach to the formation of professional and aesthetic competence of future teachers // Bulletin of the National University of Uzbekistan. - Tashkent. 2015. №1 / 4. - B. 127 - 129. (13.00.00; - №15).

12. Khudoykulov X.J. Perfect human qualities. T .: "Innovation-Intelligence", 1994.

13. Khudoykulov X.J. Morals. -T.: Navruz.2011. 